Japan. J. Med. Sci. Biol., 24, 323-327, 1971

\title{
NOTE
}

\section{STANDARDIZATION OF TRIMERESURUS FLAVOVIRIDIS (HABU) ANTIVENIN*}

Treatment with antivenin has generally been accepted as the only specific and reliable therapeutics for the snake bite (Kitajima, 1908; Chapman, 1968; Reid, 1968), however the methods for determination of the potency of antivenins have been debatable for many years (Schöttler, 1952; Grasset, 1957; Schöttler, 1958). Potencies of various antivenins have usually been expressed by the amount of venom neutralized by a certain amount of antivenin (Ipsen, 1938, Grasset, 1957), whereas other antitoxins are titrated against the standard antitoxin. As regards Trimeresurus flavoviridis $(\mathrm{Habu})$ antivenin, the animal unit determined either by $\alpha$-procedure (Sawai et al., 1961 ) or $\beta$-procedure (Kondo et al., 1965 a) had been used for many years. Kondo et al. (1965 a, b) criticized such an animal unit not expressing the proper potency of Habu antivenin and claimed that the relative potency to a stable standard antivenin should be used. They also demonstrated that crude Habu venom was inadequate as the test toxin for determination of the relative potency as it contains multiple toxic principles causing similar biological responses but having different immunological specificities. The end point of neutralization of the venom with an antivenin is dependent upon such toxic component which is the least neutralizable by the antivenin preparation to be tested. The potency determination of the biological substance is valid only when the characteristic response is caused by a single effective constituent of the test subject and of the standard (Jerne and Wood, 1949). If the reaction system is complicated as stated above, it is not certain whether the end points of the toxin-antitoxin mixture with various preparations are determined with the same component. The titers obtained under such condition may not be compared each other and the validity of such an assay is quite doubtful. They came to a conclusion that all the main toxic principles in the venom should be separated and each principle be used as the test toxin. By the use of the purified toxic principles as the test toxins, it became possible to determine accurately the potency of various antivenin preparations in terms of the relative value to a standard antivenin. This paper describes a practical method for determination of the potency of Habu antivenin based on the theory stated by Kondo et al. (1965 a, b).

Since Habu venom contains a main lethal and two hemorrhagic principles, HR1 and HR2 (Ohsaka et al., 1960), the potency of Habu antivenin should be determined in terms of three activities, viz. anti-lethal toxin, anti-HR1 and anti-HR2. Anti-lethal toxin was determined by the mouse intravenous method and anti-HR1 and anti-HR2 were by the rabbit intracutaneous method.

Standard (Habu) Antivenin No. 1 was a lyophilized preparation of $\mathrm{Habu}$ antivenin which was purified by pepsin digestion of a pooled serum specimen from several horses

* Technical details of the method has been also described in the document (1965). 
immunized with crude Habu venom. The standard had all the three antitoxic activities stated above. One gram of this preparation was defined to contain 57,750 units each of anti-lethal toxin, anti-HR1 and anti-HR2 (Ministry of Health and Welfare, 1965). The preparation is kept at the National Institute of Health, Tokyo and distributed as a solution containing 200 units per $\mathrm{ml}$.

Test toxins. Two toxin preparations, HR1 and HR2, were prepared by the method described by Omori-Satoh et al. (1967) and Takahashi and Ohsaka (1970) and lyophilized. The HR1 preparation was used to determine the anti-HR1 and anti-lethal toxin contents since the main part of the lethal toxin was always contained in the HR1 preparation; the HR2 preparation was used only for anti-HR2.

Test doses of the test toxins were defined as follows: (1) Test dose (TD) for the titration of anti-lethal toxin. The titration was carried out at $10 \mathrm{~L}+$ level. A test dose equivalent to $10 \mathrm{~L}+$ is such an amount of the HR1 preparation that will kill $50 \%$ of the mice within $48 \mathrm{hr}$ when combined with 10 units of the standard antivenin and injected intravenously. (2) Test dose for anti-HR1 and HR2. The titrations were carried out at $1 \mathrm{LR}$ level for both anti-HR1 and anti-HR2. A test dose (1 LR) is an amount of the HR1 or HR2 preparation that will cause hemorrhage of $10 \mathrm{~mm}$ in diameter in $24 \mathrm{hr}$ when combined with 1 unit of the standard antivenin and injected into rabbits under the specified conditions.

Procedures of the potency test of the antivenin. (1) Toxin-antitoxin mixtures. $\mathrm{M} / 30$ phosphate buffered saline $(\mathrm{pH} 7.0)$ containing $0.02 \%$ gelatin was used as the diluent. The mixtures were prepared in an essentially similar way for all the three

Table 1. Design for the potency test of Habu antivenin (example for anti-lethal toxin)

Formal experiment

\begin{tabular}{llllll}
\hline \multicolumn{1}{c}{ Tube no. } & 1 & 2 & 3 & 4 & 5 \\
\hline Antivenin specimen (1:5)* & 0.63 & 0.8 & 1.0 & 1.25 & 1.6 \\
Test Toxin (HR1, 25TD/ml)** & 0.4 & 0.4 & 0.4 & 0.4 & 0.4 \\
Diluent & 0.97 & 0.8 & 0.6 & 0.35 & 0 \\
\hline
\end{tabular}

Mix well and keep at room temperature for $1 \mathrm{hr}$. Inject $0.2 \mathrm{ml}$ each of the mixtures into mice (i.v.).

\begin{tabular}{llllll}
\hline Control experiment & \multicolumn{1}{l}{} & & & \\
\multicolumn{1}{c}{ Tube no. } & 1 & 2 & 3 & 4 & 5 \\
\hline Standard Antivenin $(100 \mathrm{u} / \mathrm{ml})$ & 0.63 & 0.8 & 1.0 & 1.25 & 1.6 \\
Test Toxin (HR1, $25 \mathrm{TD} / \mathrm{ml})$ & 0.4 & 0.4 & 0.4 & 0.4 & 0.4 \\
Diluent & 0.97 & 0.8 & 0.6 & 0.35 & 0 \\
\hline
\end{tabular}

Mix well and keep at room temperature for $1 \mathrm{hr}$. Inject $0.2 \mathrm{ml}$ each of the mixtures into mice (i.v.).

* Test specimens are diluted on the basis of the expected unitage; when a specimen is expected to contain $500 \mathrm{u} / \mathrm{ml}$ of anti-lethal toxin, it is diluted to $1: 5$.

** TD: Test dose determined by the mice intravenous method. 
antitoxins above stated. An example of preparing the mixtures is illustrated in Table 1. Each test toxin was so diluted as to contain $25 \mathrm{TD}$ 's per $\mathrm{ml}$ and $0.4-\mathrm{ml}$ portions were distributed into test tubes. Each tube was added with various amounts of the antitoxin solution spaced at $25 \%$ increment and the total volume was made up to $2 \mathrm{ml}$ with the diluent. At least 5 dilutions were made for the standard and each test preparation. The mixtures were kept at room temperature for $1 \mathrm{hr}$ and inoculated.

(2) Inoculation into animals. Mice weighing 14-17 g were used for the titration of anti-lethal toxin. Each mouse was injected intravenously with $0.2 \mathrm{ml}$ of each toxin-antitoxin mixture and observed for $48 \mathrm{hr}$. At least 4 mice were used for each mixture. For the titration of anti-HR1 and anti-HR2, male rabbits weighing $2500 \mathrm{~g}-$ $3000 \mathrm{~g}$ were used. A $0.2-\mathrm{ml}$ amount of each mixture was inoculated intracutaneously into the depilated back skin of at least two rabbits and the results were read from the inner side of the skin $24 \mathrm{hr}$ after the injection, as described by Kondo et al. (1960).

(3) Calculation of the potency was carried out by comparing the results of the test preparation with those of the standard. The minimum detectable levels by the present method are $63 \mathrm{u} / \mathrm{ml}, 6.3 \mathrm{u} / \mathrm{ml}$ and $6.3 \mathrm{u} / \mathrm{ml}$, respectively for anti-lethal toxin, anti-HR1 and anti-HR2. It is desirable to choose test toxins having an adequate direct toxicity per test dose; $6 \mathrm{LD}_{50} / \mathrm{TD}$ or $60 \mathrm{MHD} / \mathrm{TD}$ for HR1 and $20 \mathrm{MHD} / \mathrm{TD}$ for HR2 are suitable to obtain reproducible results.

Errors of the potency determined by a well designed experiment are about $20 \%$ : Lower titers of antitoxins can be determined at $5 \mathrm{~L}+$ or $\mathrm{LR} / 10$ level of the test toxins. The results would be less accurate if the titrations are made at still lower levels. Omori-Satoh et al. (1967) showed that titers of antivenins determined with different batches of HR1 and HR2 preparations agreed well, even when test toxins purified by two entirely different procedures were used. These facts suggest that the potency of Habu antivenin can be determined with an accuracy comparable to other

Table 2. Comparison of the potencies obtained by the two methods

\begin{tabular}{|c|c|c|c|c|}
\hline \multirow{2}{*}{$\begin{array}{l}\text { Antivenin } \\
\text { preparation }\end{array}$} & \multirow{2}{*}{ Old method* } & \multicolumn{3}{|c|}{ New method ${ }^{* *}$} \\
\hline & & Anti-lethal toxin & Anti-HR1 & Anti-HR2 \\
\hline $\mathrm{Y}-51$ & 290 & 730 & 450 & 800 \\
\hline Y-59 & 330 & 800 & 800 & 900 \\
\hline $\mathrm{Y}-61$ & 350 & 560 & 480 & 670 \\
\hline $\mathrm{Y}-63$ & 720 & 1100 & 670 & 710 \\
\hline $\mathrm{Y}-65$ & 720 & 830 & 640 & 750 \\
\hline $\mathrm{Y}-66$ & 720 & 830 & 800 & 1000 \\
\hline $\mathrm{Y}-67$ & 910 & 1050 & 800 & 800 \\
\hline $\mathrm{Y}-70$ & 370 & 410 & 530 & 470 \\
\hline $\mathrm{Y}-72$ & 670 & 750 & 710 & 950 \\
\hline $\mathrm{Y}-80$ & 310 & 940 & 710 & 500 \\
\hline $\mathrm{Y}-81$ & 490 & 1130 & 850 & 480 \\
\hline $\mathrm{Y}-82$ & 250 & 480 & 850 & 600 \\
\hline
\end{tabular}

* Animal unit determined in mice by $\boldsymbol{\beta}$-procedure using a crude venom (Kondo et al., 1965 a).

** Relative potencies to the standard antivenin. 
antitoxins.

Table 2 shows the comparison between results of the assay carried out by the two methods; the above proposed method (new method) and the method previously used (old method). The titers by the latter were expressed in terms of the number of $\mathrm{LD}_{50}$ of a reference venom (crude) neutralized by $1 \mathrm{ml}$ of the antivenin tested (Kondo et al., 1965 a). As will be seen, several antivenin preparations showing the same titer by the old method were different greatly in their composition of antitoxins when determined by the new method. The new method is useful for finding such subtle difference in the antitoxin composition and makes it possible to prepare antivenin preparations of constant potency by mixing several batches of preparations with different composition. The method is also useful in improving procedures for purification of antivenin for its accuracy and reproducibility. Furthermore, it has become possible to study Habu toxoid in a proper manner only after the method for antivenin standardization was established (Sadahiro et al., 1970; Kondo et al., 1970).

\section{ACKNOWLEDGEMENT}

We wish to express our gratitude to the Division of Public Health, Kagoshima Prefecture, Japan, for their generous gifts of Habu venom.

\section{REFERENCES}

Chapman, D. S. (1968): Symptomatology, Pathology, and treatment of the bites of venomous snakes of Central and Southern Africa. in "Venomous Animals and their Venoms" (ed. by W. Bücherl, E. E. Buckley and V. Deulofeu), I, 463-527, Academic Press Inc., London.

GRASSET, E. (1957): Survey of assay methods of antivenins. Bull. World Health Organ., 16, 79-122.

IPSEN, J. (1938): Progress report on the possibility of standardizing anti-snake-venom sera. Bull. World Health Organ., VII, 785-802.

JERNE, N. K. AND WOOD, E. C. (1949): The validity and meaning of the results of biological assays. Biometrics, 5, 273-299.

Kitajima, T. (1908): On Habu snake venoms and serotherapy with their antivenines. Saikingaku Zasshi (J. Bacteriol.), No. 154, 541-556 (text in Japanese).

Kondo, H., Kondo, S., IKezawa, H., Murata, R. AND OHSAKA, A. (1960): Studies on the quantitative method for the determination of hemorrhagic activity of Habu snake venom. Japan. J. Med. Sci. Biol., 13, 43-51.

Kondo, H., Kondo, S., SAdahiro, S., Yamauchi, K., Ohsaka, A. ANd Murata, R: (1965 a): Standardization of antivenine. I. A method for determination of antilethal potency of Habu antivenine. Japan. J. Med. Sci. Biol., 18, 101-110.

Kondo, H., Kondo, S., SAdahiro, S., Yamauchi, K., OHSAKa, A. ANd Murata, R. $(1965 \mathrm{~b})$ : Standardization of antivenine. II. A method for determination of antihemorrhagic potency of $\mathrm{Habu}$ antivenine in the presence of two hemorrhagic principles and their antibodies. Japan. J. Med. Sci. Biol., 18, 127-141.

Kondo, H., Sadahiro, S., Kondo, S., Yamauchi, K., Honjo, S., Cho, F., Ohsaka, A. AND MURATA, R. (1970): Immunogenicity in monkeys of a combined toxoid from the main toxic principles separated from Habu snake venom. Japan. J. Med. Sci. Biol., $23,413-418$.

Ministry of Health and Welfare (1965): Minimum Requirements for Antivenine. p. 16-26, Tokyo.

OHSAKA, A., IKeZAwA, H., Kondo, H., Kondo, S. AND UChidA, N. (1960): Haemorrhagic 
activities of Habu snake venom, and their relations to lethal toxicity, proteolytic activities and other pathological activities. Brit. J. Exptl. Pathol., 41, 478-486.

OMORI-SATOH, T., OHSAKA, A., Kondo, S. AND KondO, H. (1967): A simple and rapid method for separating two hemorrhagic principles in the venom of Trimeresurus favoviridis. Toxicon, 5, 17-24.

REID, H. A. (1968): Symptomatology, pathology and treatment of Land snake bite in India and Southeast Asia. in "Venomous Animals and their Venoms", (ed. by W. Bücherl, E. E. Buckley and V. Deulofeu), I, 611-642, Academic Press Inc., London.

Sadahiro, S. Kondo, S., Yamauchi, K., Kondo, H. and Murata, R. (1970): Studies on immunogenicity of toxoid from Habu (Trimeresurus flavoviridis) venom. Japan. J. Med. Sci. Biol., 23, 285-289.

Sawai, Y., Makino, M., Miyazaki, S., Kato, K., Adachi, H., Mitsuhashi, S. AND OKONOGI, T. (1961): Studies on the improvement of treatment of Habu snake bite. I. Studies on the improvement of Habu snake antivenine. Japan. J. Exp. Med., 31, 137-150.

Schöttler, W. H. A. (1952): Problem of antivenin standardization. Bull. World Health Organ., $V, 293-320$.

SCHÖTTLER, W. H. A. (1958): Reference toxins for antivenin standardization. Bull. WHO, 19, 341-361.

TAKahashi, T. AND OHSAKa, A. (1970): Purification and some properties of two hemorrhagic principles (HR2a and HR2b) in the venom of Trimeresurus flavoviridis; complete separation of the principles from proteolytic activity. Biochem. Biophys. Acta, 207, 65-75.

The 2nd Department of Bacteriology

National Institute of Health,

Shinagawa-ku, Tokyo 141, Japan
HISASHI KONDO*

SATORU KONDO

SEIJI SADAHIRO

KIYOSUMI YAMAUCHI

RYOSUKE MURATA

Received: July 2nd, 1971

* Present address: Chiba Serum Institute, 2-6-1 Konodai, Ichikawa, Chiba 272, Japan. 近藤 久 (千葉県血清研究所)

近藤 了・貞弘 省二・山内 清澄・村田 良介 (国立予防衛生研究所 細菌第二部) 